\title{
Apicystis gen nov and Apicystis bombi (Liu, Macfarlane \& Pengelly) comb nov (Protozoa: Neogregarinida), a cosmopolitan parasite of Bombus and Apis (Hymenoptera: Apidae)
}

\author{
JJ Lipa 1, O Triggiani 2 \\ 1 Institute of Plant Protection, Miczurina 20, 60-318 Poznan, Poland; \\ 2 Istituto di Entomologia Agraria, Universita degli Studi, via Amendola 165/A, 70125 Bari, Italy
}

(Received 20 May 1995; accepted 22 December 1995)

Summary - A new genus Apicystis and a new combination Apicystis bombi (Liu, Macfarlane \& Pengelly) is proposed for a neogregarine parasitic on Bombus spp and Apis mellifera. The genus Apicystis is characterized by having navicular oocysts containing only four sporozoites and basically differs from the genus Mattesia which has spindle oocysts with eight sporozoites. This parasite was recorded in ten species of Bombus in Europe and North America, but has been observed only once in Apis mellifera in Finland.

Apicystis / Apis / Bombus / new genus / protozoan / parasite

\section{INTRODUCTION}

Based on research undertaken in Italy, 1988 and in Finland, 1990 we published a short note (Lipa and Triggiani, 1992) in which we reported finding a neogregarine parasite on Bombus hortorum, $B$ terrestris and Apis mellifera. After describing the morphological characteristics of the neogregarine, at the end of our note we stated 'All these features indicate that this neogregarine constitutes both a new species and a new genus. It also represents the first record of neogregarine infection in the Apidae'. At that time we were not familiar with the paper by Liu et al (1974) in which these authors described Mattesia bombi Liu, Macfarlane \& Pengelly from Bombus spp in Canada. Further studies (Macfarlane et al $1995,1996)$ strongly support our original opinion that the involved neogregarine does not belong to the genus Mattesia, but represents a new genus which we describe in this paper.

\section{MATERIAL AND METHODS}

As previously reported (Lipa and Triggiani, 1992) infected queens and workers of Bombus spp 
were collected in Italy in open-air in 1988, and one infected worker of Apis mellifera was collected in hive in Finland in 1990. In July of 1995 additional infected males and queens of $B$ terrestris were collected at the University Campus in Bari, Italy, and from fields at Valenzano, 15 $\mathrm{km}$ from Bari. Collected insects were dissected and their fat body tissue and gut were examined under a light microscope. Morphology and life cycle of the pathogen were studied on smeared fat body tissue preparations fixed for $2 \mathrm{~min}$ in methanol and stained in $0.25 \%$ Giemsa for 8-12 h.

In spite of our efforts we were not able to locate and access any oocyst material, stained microscope slides or photos concerning Mattesia bombi occurring in Bombus spp in Canada on which the original description was based. According to information obtained from RP Macfarlane (Christchurch, New Zealand) and P Kevan (Guelph, Canada), all documentation material concerning $M$ bombi, deposited at the University of Guelph, was discarded when the authors left or retired. After making enquiries to several bumble bee researchers for information and infected insect material, P Schmid-Hempel (Institute of Microbiology, ETH Zurich, Switzerland) informed us about observations of neogregarine infection in Bombus spp in Switzerland and provided photographs of its oocysts.

\section{RESULTS AND DISCUSSION}

\section{Geographic distribution, hosts and infection level}

The neogregarine concerned was first reported as Mattesia bombi (Liu et al, 1974; Macfarlane et al, 1995, 1996) in the Ontario province of Canada in the queens and some males of various Bombus spp. Of the 3045 overwintered queens examined, $5.3 \%$ were parasitized: Bombus vagans being the most heavily infected, with $8.2 \%$ of its queens parasitized (Liu et al, 1974; Macfarlane et al, 1995). Recently Macfarlane et al (1996) reported this neogregarine in France where it infected various Bombus spp. Based on the dissection of several hundred workers of various bumble bee species (Bombus spp), Schmid-Hempel (unpublished data) estimated the neogregarine infection at a level of $4-7 \%$ in Switzerland.

Neogregarine oocysts were observed in queens and workers of $B$ hortorum and $B$ terrestris collected by sweep net in Southern Italy (Apuglia) (Lipa and Triggiani, 1992). The presence of identical oocysts was noticed in one $A$ mellifera worker out of 34 collected in July 1990 from one hive of the experimental apiary of the Agricultural Research Center, Jokioinen, Finland. Microscopic examination of additional individuals of Bombus spp in Italy (Triggiani, 1991), New Zealand and Japan (Macfarlane et al, 1995), Denmark and Finland (Lipa, unpublished data) failed to reveal neogregarine infection.

In July 1995 the neogregarine infection was again detected in $B$ terrestris collected in Italy: Bari (5th): out of three males, one was one infected with neogregarine and one was infected with both neogregarine and Nosema bombi; Bari (10th): out of two males, one was infected with neogregarine and Crithidia bombi; Bari (14th) one male and one queen were infected with neogregarine; Valenzano (18th), out of three workers, two queens and ten males examined one queen and one male were infected with neogregarine.

The above data indicate that neogregarine infection is common, but its level is low in Bombus spp and sporadic in A mellifera. This is not surprising as infections of Bombus spp and $A$ mellifera by eugregarines and flagellates reach very low levels and have been reported from very few localities (Lipa and Triggiani, 1988; Macfarlane et al, 1995). However, since the parasitic neogregarine was found in Canada, Finland, France, Italy and Switzerland it must be assumed that it is a cosmopolitan parasite so it is only a matter of time before it is reported from other countries. 


\section{Life Cycle}

Electron microscopy studies undertaken by Liu et al (1974), combined with our previous observations (Lipa and Triggiani, 1992) and the results of the present study, provide sufficient data to allow an understanding of the complete life cycle of this neogregarine in host insects and recognition of the main stages necessary for its identification and the description of the new genus.

The sporozoites that emerge in the intestine from ingested oocysts penetrate through the midgut wall into the body cavity and infect the fat body cells in which they grow, develop and multiply. Heavily infected fat tissue is strikingly white and much reduced but microscopic examination for presence of oocysts is required to diagnose infection and identify the pathogen.

On smeared gut and fat body preparations of the infected Bombus spp and $A$ mellifera oocysts various developmental stages were observed. Micronuclear meronts have diameters up to $45 \mu \mathrm{m}$ and contain up to 40 small nuclei, each measuring $1.3 \mu \mathrm{m}$. Later micronuclear merozoites are produced that are oval or elongated and measure 5-9 x 2.5-3.5 $\mu \mathrm{m}$. Macronuclear meronts measure $20 \times 15 \mu \mathrm{m}$ and give rise to ovoidal or pyriform macronuclear merozoits (gamonts) 5-8 $\mu \mathrm{m}$ in diameter. Through the process of gametogony, oocysts containing four sporozoites are produced (fig 2). The presence of empty oocysts in the tissue smears suggests that autoinfection may take place. Liu et al (1974) reported the presence of oocysts in the spermatheca of mated queens and this indicates a possible congenital means of transmission of the neogregarine.

\section{Oocyst morphology}

The oocysts observed in Bombus spp from Canada, Italy and Switzerland and in A mel- lifera from Finland were identical and this allows us to conclude that in all cases of infection the same neogregarine species is involved. The oocysts were navicular in shape and the majority of them had distinct caps. Fresh oocysts measured in water were 16.2-21.6 $\mu \mathrm{m}$ long and $5.6 \mu \mathrm{m}$ wide (fig 1); oocysts after fixing and staining were 11.1-14.4 $\mu \mathrm{m}$ long and 3.6-5.4 $\mu \mathrm{m}$ wide. Inside the stained young oocysts, four uninucleate sporozoites were readily visible (fig 2). However, they became less visible in the mature oocysts.

\section{Taxonomic position}

Liu et al (1974) described this neogregarine as Mattesia bombi and placed it into the family Ophryocystidae (the authors misspelled it as Ophrocystidae). However, the life cycle and morphology of meronts and oocysts (spores) indicate that the neogregarine infecting Bombus spp and A mellifera belongs to the family Lipotrophidae in the order Neogregarinida (= Schizogregarinida) (Levine, 1988). According to Levine (1988) the family Lipotrophidae contains five genera: Farinocystis, Lipocystis, Lipotropha, Mattesia, and Menzbieria which have oocysts that contain always eight sporozoites. Levine (1988) incorrectly placed $M$ bombi, which has navicular oocysts with four sporozoites (figs 1 and 2) into the genus Mattesia which has quite different spindle oocysts with eight sporozoites (figs 3 and 4).

For the reasons explained above, we remove the neogregarine Mattesia bombi infecting Bombus and Apis from the Mattesia genus and classify it as Apicystis bombi (Liu et al, 1974) comb nov in a newly established genus Apicystis gen nov. This generic name is proposed to emphasize that the neogregarine is associated with insects belonging to the family Apoidea. 


\section{Host specificity}

All host records refer to insects infected in nature, and thus far no tests on the infec- tivity of $A$ bombi to bumble bees or honey bees have been conducted. Since infection has been recorded in ten species of Bombus, on two continents and in four
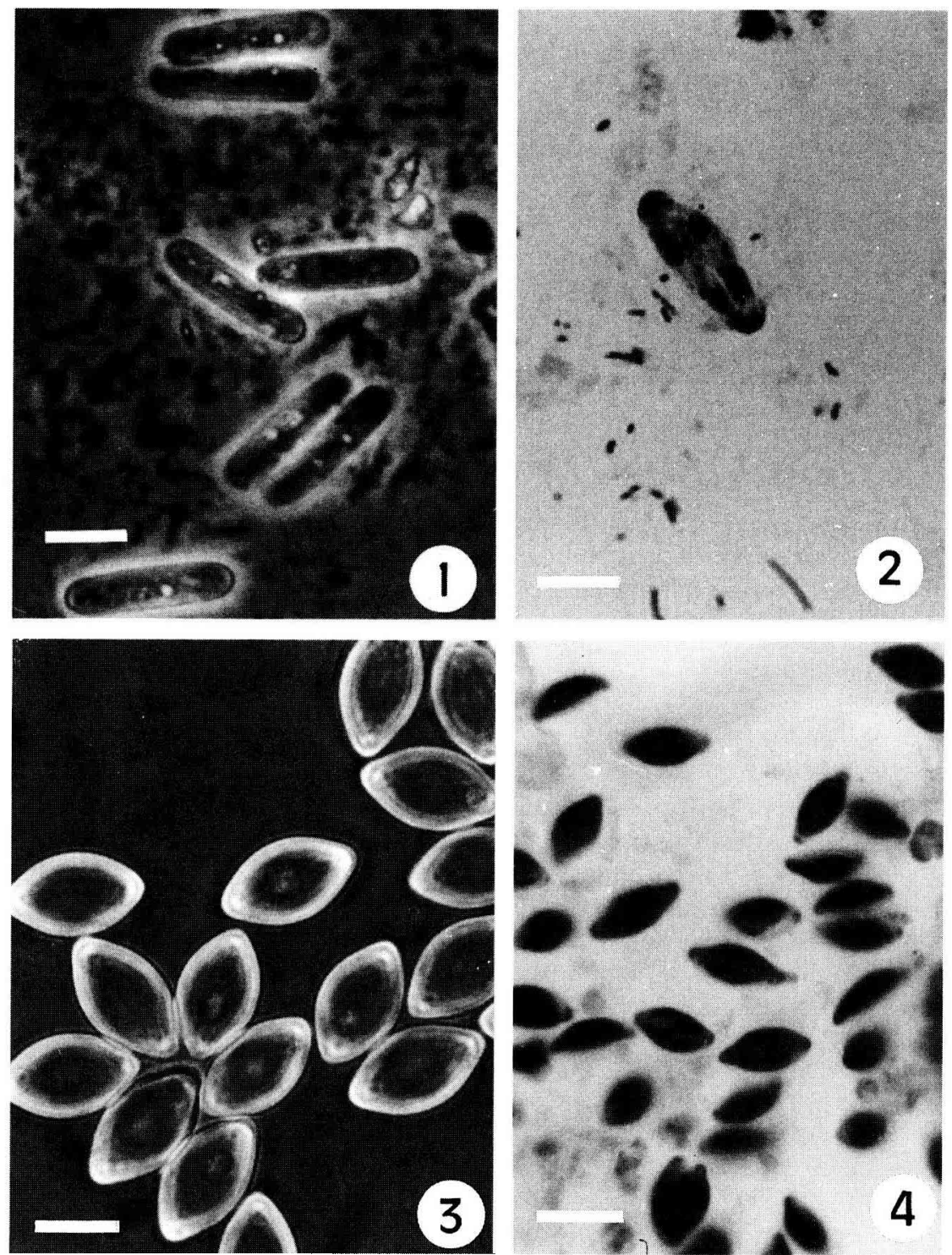

Figs 1-2. Apicystis bombi. 1. Fresh oocysts from tissues of $B$ terrestris (bar $=8 \mu \mathrm{m})$. 2. Fixed and stained young oocysts from $A$ mellifera with four visible uninucleate sporozoites (bar $=7 \mu \mathrm{m}$ ).

Figs 3-4. Mattesia dispora. 3. Fresh oocysts from tissues of Anagasta kühniella (bar $=7 \mu \mathrm{m}$ ). 4. Fixed and stained oocysts (bar $=11 \mu \mathrm{m}$ ). 
countries, it may be concluded that bumble bees are the principal hosts for $A$ bombi. Observations in Finland indicate that $A$ bombi can also infect honey bees ( $A$ mellifera). The oocysts and merozoites present in the fat body of a honey bee worker were identical to oocysts and merozoites observed in fat body cells of queens, males and workers of bumble bees in other countries. This observation, however, requires confirmation by further studies on host and tissue specificity, to determine whether only one or two neogregarine species are involved. A case of such high host specificity has been described already with respect to Nosema bombi and Nosema apis, infecting Bombus spp and Apis mellifera respectively (van den Ejinde and Vette, 1993; Weiser, 1978).

\section{Apicystis gen nov}

\section{Diagnosis}

Intracellular development in fat body cells and possibly in midgut epithelium. During merogony, macronuclear and micronuclear meronts are produced. Navicular oocysts (spores) are formed singly, they have polar caps and contain four uninucleate sporozoites.

\section{Type species}

Apicystis bombi (Liu, Macfarlane \& Pengelly, 1974) comb nov with the characteristic of the genus. Navicular oocysts; when fresh measured 16.2-21.6 x 5.6 $\mu \mathrm{m}$ and when fixed and stained 11.1-14.4 x 3.6-5.4 $\mu \mathrm{m}$. Development in the fat body; oocysts also seen in midgut.

\section{Hosts}

Recorded in naturally infected queens, workers and males of Bombus affinis, $B$ bimaculatus, $B$ fervidus, $B$ griseocollis, $B$ hortorum, $B$ impatiens, $B$ perplexus, $B$ terrestris, $B$ terricola, and $B$ vagans in Canada, France, Italy and Switzerland, and in one honey bee (A mellifera) worker in Finland.

\section{ACKNOWLEDGMENTS}

The senior author (JJL) expresses his thanks to the Institute of Agricultural Entomology of the University of Bari for providing the funds. Special thanks are expressed to P Schmid-Hempel (ETH Zurich, Switzerland) for information on the parasite occurrence in Switzerland and for providing us with a photograph of fresh oocysts.

Résumé - Apicystis gen nov and Apicystis bombi (Liu, Macfarlane \& Pengelly) comb nov (Protozoa: Neogregarinida), parasite cosmopolite de Bombus et d'Apis (Hymenoptera: Apidae). Un nouveau genre Apicystis et une nouvelle combinaison Apicystis bombi (Liu, Macfarlane \& Pengelly) sont proposés pour le parasite néogrégarine de Bombus spp et d'Apis mellifera. Le genre Apicystis se caractérise par des oocystes naviculaires ne renfermant que quatre sporozoïtes (fig 2) et diffère fondamentalement de Mattesia qui possède des oocystes en fuseau avec huit sporozoïtes. Les oocystes frais mesurent $16,2-21,6 \mu \mathrm{m}$ de long et $5,6 \mu \mathrm{m}$ de large (fig 1). Ce parasite a été observé chez dix espèces de Bombus en Europe et en Amérique du Nord et une seule fois chez $A$ mellifera en Finlande. Des études complémentaires sur la spécificité de l'hôte et du tissu sont nécessaires pour confirmer s'il s'agit d'une seule ou de deux espèces différentes.

Apicystis / protozoaire / parasite / Apis mellifera / Bombus / genre nouveau

Zusammenfassung - Apicystis gen nov und Apicystis bombi (Liu, Macfarlane \& 
Pengelly) comb nov (Protozoa: Neogregarinida), ein kosmopolitischer Parasit von Bombus und Apis (Hymenoptera: Apidae). Für einen neogregariniden Parasiten von Apis mellifera und Bombus spp wird eine neue Gattung Apicystis und eine neue Kombination Apicystis bombi (Liu, Macfarlane \& Pengelly) vorgeschlagen. Die Gattung Apicystis wird durch naviculäre Oozysten mit nur vier Sporozoiten characterisiert (Abb 2) und unterscheidet sich grundlegend von der Gattung Mattesia mit spindelförmigen Oozysten und acht Sporozoiten. Frische Oozysten sind 16,2-21,6 $\mu \mathrm{m}$ lang und $5,6 \mu \mathrm{m}$ breit (Abb 1). Der Parasit wurde bisher in unterschiedlichen Bombus-Arten in Europa und Nordamerika, aber nur einmal bei Apis mellifera in Finnland gefunden. Zur endgültigen Klärung der Frage, ob nur eine oder zwei neogregarinide Arten vorliegen sind weitere Untersuchungen der Wirts-und Gewebespezifität erforderlich.

Apicystis / Apis / Bombus / Neogregarinen / Protozoen / Parasiten / neue Gattung

\section{REFERENCES}

Levine ND (1988) The Protozoan Phylum Apicomplexa. CRC Press, Boca Raton, Vol I, $203 \mathrm{p}$

Lipa JJ, Triggiani O (1988) Crithidia bombisp n, a new flagellated parasite of a bumble bee Bombus terrestris $L$ (Hymenoptera, Apidae). Acta Protozool 27, 287-290

Lipa JJ Triggiani O (1992) A newly recorded neogregarine (Protozoa, Apicomplexa), parasite in honey bees (Apis mellifera) and bumble bees (Bombus spp). Apidologie 23, 533-536

Liu HJ, Macfarlane RP, Pengelly DH (1974) Mattesia bombin sp (Neogregarinidae: Ophrocystidae), a parasite of Bombus (Hymenoptera: Apidae). J Invertebr Pathol 23, 225-231

Macfarlane RP, Lipa JJ, Liu HJ (1995) Pathogens and internal enemies of bumble bees Bombus. Bee World $76,130-\uparrow 48$

Maciarlane, RP, Robert, P, Pouvreau, A (1996) The bee fat body sporozoan Apicystis bombi: a possible bumble bee parasite. J Apic Res 35: (In press)

Triggiani $O$ (1991) Micro e macroorganismi endozoici in adulti di Bombus Latr e Psithyrus Lep (Hymenoptera: Apidae). Atti XVI Congr Nazionale Italiano di Entomologia (Bari-Martina Franca 23-28 September 1991), 587-597

van den Ejinde J, Vette N (1993) Nosema infection in honeybees (Apis mellifera L) and bumblebees (Bombus terrestris L). Proc Section Exp \& Appl Entomol of the Neth Entomol Soc 4, 205-208

Weiser J (1978) Morphological differences of Nosema apis and Nosema bombi. Progress in Invertebrate Pathology 1958-1978, int Collog Invertebr Pathol, September 11-17, 1978, Prague, 241-242 